\title{
Psychiatric Disorders in Iranian Alcohol Users
}

\author{
Ali Kheradmand ${ }^{1}$, Seyed Saeed Sadr², Ali Jahandideh², \\ Elham Mirshah ${ }^{3}$ \\ ${ }^{1}$ Taleghani Hospital Research Development Committee, Behavioral Sciences Research \\ Center, Shahid Beheshti University of Medical Sciences, Tehran, Iran, ${ }^{2}$ Shahid Beheshti \\ University of Medical Sciences, Tehran, Iran, ${ }^{3}$ Department of psychiatric nursing, school \\ of nursing and midwifery, Shiraz University of Medical Sciences, Shiraz, Iran
}

\begin{abstract}
Introduction- there is a close relationship between alcohol dependence and psychiatric disorders. A large number of people who use alcohol are suffering from psychiatric disorders, so identifying and treating of psychiatric disorder is vitally important in alcohol users. The aim of this study was evaluate the prevalence of axis I psychiatric disorders in Iranian alcohol users in 2017. Subjects \& Methods:- in this cross-sectional study, 105 patients who were attendance to the Iranian National Center for Addiction Studies (INCAS) were interviewed. Alcohol consumption questionnaire and demographic questionnaire were completed for all patients and the prevalence of psychiatric disorders with SCID-1 was evaluated. The information collected was analyzed with SPSS software version 22. Results:- about $45 \%$ of participants except alcohol use had no other psychiatric illness and 55\% had psychiatric disorders. 5.34\% had bipolar disorders and $4.22 \%$ had severe depression, respectively, and the incidence of OCD was in $2.5 \%$. History of referral to the psychiatrist was in $23.8 \%$ and history of admission to the psychiatric ward was $16.2 \%$. Also, the use of other non-alcoholic substances in the patients was examined; the most consumed was opium in $26.7 \%$, followed by cannabis with 16.2\%. Conclusion:- regarding the high prevalence of axis I psychiatric disorders among alcohol use disorders, a complete interview and history of psychiatry disorders is essential.
\end{abstract}

Key words: psychiatric disorders, alcohol users, Iran.

Copyright (C) 2020 KBCSM, Zagreb

e-mail: alcoholism.kbcsm@gmail.com•www.http://apr.kbcsm.hr

\section{Introduction}

Due to the high prevalence of alcohol consumption, the assessment of alcohol consumption is an important part of any medical or psychiatric examination. Almost

\footnotetext{
Correspondence to:

Ali Kheradmand, MD, PhD,

Taleghani Hospital,Shahid Beheshti University of Medical

Sciences, Velenjak, Tehran, Iran

Phone : + 98912 021-6858

Fax: + 98212 243-2581

E-mail: a.alikheradmand@sbmu.ac.ir
}

a clinical sign of some psychiatric disorders can be linked to the effects of abuse, although alcoholism does not describe as a specific psychiatric disorder [1]. Understanding the effects of alcohol and the clinical importance of alcohol-related disorders in psychiatry is unnecessary. Dependence on alcohol is a chronic disorder that has profound social, psychological, and economic impacts, which, in addition to endangering physical and mental health, imposes 
a high cost on society and government and the family [2-4].

Based on this there is a close relationship between alcohol dependence and psychiatric disorders. A large number of people who use alcohol are suffering from psychosocial disorder, so diagnosis and treatment of the psychiatric disorder in alcohol-dependent patients is very important $[5,6]$. Many patients with psychiatric disorders use self-healing alcohol when prescribed drugs do not diminish their symptoms, or when they do not have access to prescribed medications $[7,8]$.

Different causes may cause this co morbidity, including genetic causes. It also may have inherited a common gene for alcoholism and genetic variation such as mood and anxiety disorder and psychosis. In bipolar patients, heavy alcohol intake often results in a mania period $[9,10]$. Understanding the effects of alcohol and the clinical significance of psychiatric disorders along with psychiatric condition were unclear, and the condition in which alcohol consumption is associated with other mental illnesses is more than a general belief. Primary psychiatric disorder may be a cause for the onset and continued use of alcohol and dependence on alcohol $[11,12]$. So alcohol consumption and addiction may increase the risk of psychiatric illness or lead to persistent illness, so recognizing psychiatric disorders, especially the first one, is important in these people. Based on mentioned the aim of this study was evaluate the prevalence of psychiatric disorders in alcohol users' attendance to Tehran outpatient alcohol withdrawal clinics in 2016.

\section{Subjects and methods}

\section{Study setting}

This study as was an analytical cross-sectional and clinical-based study conducted on patients with alcohol use disorder.

\section{Study population}

Study populations were all patients with alcohol use disorders. Based on this, 105 patients who were attendant to the Iranian $\mathrm{Na}$ tional Center for Addiction Studies (INCAS) in 2017 evaluated.

\section{Measurements}

After obtaining permits and coordination with relevant authorities, for the implementation of the plan, alcohol addicted patients who went to the INCAS Center to withdraw were considered as study group. The study population included all patients who used alcohol and referred to treat and withdraw the alcohol consumption. First, a demographic questionnaire (age, gender, educational status, occupation, marital status, duration of alcohol consumption and type of other substance) was filled out for all patients. Then Structured Clinical Interview for DSM -IV Axis I Disorders (SCID-I) was provided to all patients, and finally, the data were analyzed by standard methods. Individuals were assured of the secrecy and preservation of personal information, and written consent was given to them.

\section{Ethical considerations}

Ethical issues completely observed by authors. The study group adheres to the principles of medical ethics introduced by the Health Ministry and the Declaration of Helsinki and legislation in medical ethics commit- 
Table 1. Percentage of psychiatric disorders in Iranian alcohol users.

\begin{tabular}{lc}
\hline Disorders Type & $\mathrm{N}(\%)$ \\
\hline Schizophrenia and Other Psychotic Disorders & $6(5.7)$ \\
Bipolar disorders & $20(19.0)$ \\
Major Depression & $13(12.4)$ \\
Mild Depression & $5(4.8)$ \\
Anxiety Disorders & $7(6.7)$ \\
OCD & $3(2.9)$ \\
PTSD & $4(3.8)$ \\
None & $47(44.8)$ \\
\hline
\end{tabular}

tee of Shahid Beheshti University of Medical Sciences. In addition, ethical committee of Shahid Beheshti University of Medical Sciences approved protocol of study.

\section{Statistical analysis}

The data were analyzed by SPSS program and $\mathrm{P}<0.05$ was considered as significant value. We consider independent sample $\mathrm{T}$ test for quantitative variables and $\mathrm{X} 2$ test for qualitative variables.

\section{Results}

We evaluated 105 patients as our study group, of evaluated patients, $45 \%$ had no mental illness, while $5.34 \%$ had bipolar disorders and $4.22 \%$ had severe depression, respectively, and the incidence of OCD was in $2.5 \%$ (Table 1 ). In addition the mean and standard deviation of the first age alcohol consumption among patients with mental illness were $25.6 \pm 7.1$ years and in those without mental illness, were $25.2 \pm 5.2$ years old, and after statistical evaluation, there was no significant difference between the two groups $(\mathrm{P}=0.778)$. We also observed that the duration of alcohol in both groups was about 20 years and there was no statistically significant difference between the two groups $(\mathrm{P}=$ 0.198) (Table 2). Also in comparing the in-

Table 2. Age of first consumption and duration of use in Iranian alcohol users.

\begin{tabular}{lccc}
\hline & \multicolumn{2}{c}{ Psychiatry Disorders } & \\
\cline { 2 - 3 } Variables & Positive & Negative & P Value \\
\hline Age of First Consumption & & & 0.778 \\
Mean & 25.66 & 25.22 & \\
Standard Deviation & 7.18 & 8.34 & \\
\hline Duration Use & & & 0.198 \\
Mean & 19.74 & 16.79 & \\
Standard Deviation & 12.87 & 9.76 & \\
\hline
\end{tabular}


Table 3. Characteristics of Iranian Alcohol Users.

\begin{tabular}{|c|c|c|c|c|c|}
\hline \multirow[t]{2}{*}{ Variables } & \multicolumn{4}{|c|}{ Psychiatry Disorders } & \multirow[t]{2}{*}{ P Value } \\
\hline & & & & & \\
\hline Gender & $\mathrm{N}$ & $\%$ & $\mathrm{~N}$ & $\%$ & $>0.999$ \\
\hline Male & 53 & $55.2 \%$ & 43 & $44.8 \%$ & \\
\hline Female & 5 & $55.6 \%$ & 4 & $44.4 \%$ & \\
\hline Referring to Hospital & & & & & 0.745 \\
\hline Positive & $58.8 \%$ & 10 & $41.2 \%$ & 7 & \\
\hline Negative & $54.5 \%$ & 48 & $45.5 \%$ & 40 & \\
\hline Hospitalization & & & & & $>0.999$ \\
\hline Positive & $60.0 \%$ & 6 & $40.0 \%$ & 4 & \\
\hline Negative & $54.7 \%$ & 52 & $45.3 \%$ & 43 & \\
\hline Referring to Psychiatrist & & & & & 0.404 \\
\hline Positive & $48.0 \%$ & 12 & $52.0 \%$ & 13 & \\
\hline Negative & $57.5 \%$ & 46 & $42.5 \%$ & 34 & \\
\hline Hospitalized in Psychiatric Ward & & & & & 0.745 \\
\hline Positive & $58.8 \%$ & 10 & $41.2 \%$ & 7 & \\
\hline Negative & $54.5 \%$ & 48 & $45.5 \%$ & 40 & \\
\hline $\begin{array}{l}\text { Arrested Due to Alcohol } \\
\text { Consumption }\end{array}$ & & & & & 0.115 \\
\hline Positive & $35.7 \%$ & 5 & $64.3 \%$ & 9 & \\
\hline Negative & $58.2 \%$ & 53 & $41.8 \%$ & 38 & \\
\hline $\begin{array}{l}\text { Participate in narcotic anonymous } \\
\text { (NA) meetings }\end{array}$ & & & & & 0.203 \\
\hline Positive & $41.2 \%$ & 7 & $58.8 \%$ & 10 & \\
\hline Negative & $58.0 \%$ & 51 & $42.0 \%$ & 37 & \\
\hline Consuming Other Ingredients & & & & & 0.302 \\
\hline Positive & $48.7 \%$ & 19 & $51.3 \%$ & 20 & \\
\hline Negative & $59.1 \%$ & 39 & $40.9 \%$ & 27 & \\
\hline
\end{tabular}

formation in the patients, we also observed that the related indicators included sex $(\mathrm{P}=$ 0.302), referring to hospital $(\mathrm{P}=0.302)$, hospitalization $(\mathrm{P}=0.302)$, referral to the psychiatrist $(\mathrm{P}=0.302)$, admission in the psychiatric wards $(\mathrm{P}=0.302)$, detention due to alcohol consumption $(\mathrm{P}=0.302)$, participation in NA meetings $(\mathrm{P}=0.302)$, and consumption of non-alcoholic substances $(\mathrm{P}=$ 0.302) between two groups of patients with and without psychiatric disorders have not a statistically significant difference in men- 
tal disorder. Accordingly, these cases did not have a significant effect on their mental disorders (Table 3).

\section{Discussion}

We found that about $55 \%$ of the patients as an outpatient had alcohol related psychiatric disorder at the same time, with the highest proportion of mood disorders $(36.2 \%)$. Also we found that bipolar disorder was 19\% and depression was $17.2 \%$, anxiety disorders $6.7 \%$, and schizophrenia and psychotic disorders was $5.7 \%$. In following other study that conducted for this has been discussed. In a study by Grant and associates authors found that psychological disorder related to alcohol consumption were positive in $32 \%$ to $42 \%$ with depression and $13 \%$ with anxiety disorders in the last 1 year and 40\% over the life span, and the incidence of post-traumatic stress disorder varies from $10 \%$ to $60 \%$ $[12,13]$. Meanwhile, in our study, the prevalence of depression was $17 \%$ and anxiety disorder was $7.6 \%$ and post-stress disorder was $8.3 \%$. In addition in this study, bipolar disorder was $46 \%$ and schizophrenia was $6.4 \%$. However, our study showed that $19 \%$ of patients had bipolar disorder and 6\% had schizophrenia and other psychiatric disorders, which is similar to that of schizophrenia $[13,14]$. In addition disturbance in axis 1 of psychiatric disorders diagnosis was 6.3\% in Salloum and associates study, also in this

\section{References}

1. Petry NM, Stinson FS, Grant BF. Comorbidity of DSM-IV Pathological Gambling and Other Psychiatric Disorders. J Clin Psychiatry. 2005;66:56474. study $2.2 \%$ of patients has psychiatric disorders, and the mean age of alcohol consumers in their study was 42 years. Meanwhile, in our study, about $55 \%$ of patients with disordered axis 1 was in age group of 30 to 49 years old [15].

On the other hand, in study by Dominguez and associates bipolar disorder (20.4\%), all types of depression (17\%), anxiety disorders $(8.1 \%)$, schizophrenia and delusional disorders $(9.7 \%)$ were the most common disorders in 19\% of patients [16]. In addition, about psychological disorders $2.1 \%$ had severe and mild depression, $7.6 \%$ had anxiety disorders, $7.5 \%$ had schizophrenia and other psychotic disorders [16]. Accordingly, most studies in this field have been consistent with the results of our assessment, which indicates the importance of psychological disorders in patients with alcohol abuse.

\section{Conclusion}

Regarding the high prevalence of axis I psychiatric disorders among alcohol use disorders, a complete interview and getting history of psychiatry disorders is essential.

\section{Acknowledgments}

None.

\section{Conflict of interest}

None.
2. Conway KP, Compton W, Stinson FS, Grant BF. Lifetime comorbidity of DSM-IV mood and anxiety disorders and specific drug use disorders: results from the National Epidemiologic Survey on 
Alcohol and Related Conditions. J Clin Psychiatry. 2006;67:247-57.

3. Grant BF, Goldstein RB, Saha TD, Chou SP, Jung J, Zhang H, et al. Epidemiology of DSM-5 Alcohol Use Disorder: Results From the National Epidemiologic Survey on Alcohol and Related Conditions III. JAMA Psychiatry. 2015;72:757-66.

4. Blanco C, Hasin DS, Wall MM, Flórez-Salamanca L, Hoertel N, Wang S, et al. Cannabis Use and Risk of Psychiatric Disorders: Prospective Evidence From a US National Longitudinal Study. JAMA psychiatry. 2016;73:388-95.

5. Grant BF, Goldstein RB, Smith SM, Jung J, Zhang $\mathrm{H}$, Chou SP, et al. The Alcohol Use Disorder and Associated Disabilities Interview Schedule-5 (AUDADIS-5): Reliability of substance use and psychiatric disorder modules in a general population sample. Drug Alcohol Depend. 2015;148:27-33.

6. Nikolova YS, Knodt AR, Radtke SR, Hariri AR. Divergent responses of the amygdala and ventral striatum predict stress-related problem drinking in young adults: possible differential markers of affective and impulsive pathways of risk for alcohol use disorder. Mol Psychiatry. 2016;21:348-56.

7. Verhulst B, Neale MC, Kendler KS. The heritability of alcohol use disorders: a meta-analysis of twin and adoption studies. Psychol Med. 2015;45:106172.

8. Kerridge BT, Pickering RP, Saha TD, Ruan WJ, Chou SP, Zhang H, et al. Prevalence, sociodemographic correlates and DSM-5 substance use disorders and other psychiatric disorders among sexual minorities in the United States. Drug Alcohol Depend. 2017;170:82-92.

9. Lai HMX, Cleary M, Sitharthan T, Hunt GE. Prevalence of comorbid substance use, anxiety and mood disorders in epidemiological surveys, 1990 2014: A systematic review and meta-analysis. Drug Alcohol Depend. 2015;154:1-13.
10. Hasin DS, Greenstein E, Aivadyan C, Stohl M, Aharonovich E, Saha T, et al. The Alcohol Use Disorder and Associated Disabilities Interview Schedule-5 (AUDADIS-5): procedural validity of substance use disorders modules through clinical re-appraisal in a general population sample. Drug Alcohol Depend. 2015;148:40-6.

11. Weinberger AH, Funk AP, Goodwin RD. A review of epidemiologic research on smoking behavior among persons with alcohol and illicit substance use disorders. Prev Med. 2016;92:148-59.

12. Grant BF, Chou SP, Saha TD, Pickering RP, Kerridge $\mathrm{BT}$, Ruan WJ, et al. Prevalence of 12-Month Alcohol Use, High-Risk Drinking, and DSM-IV Alcohol Use Disorder in the United States, 20012002 to 2012-2013: Results From the National Epidemiologic Survey on Alcohol and Related Conditions. JAMA psychiatry. 2017;74:911-23.

13. Grant BF. Prevalence and correlates of alcohol use and DSM-IV alcohol dependence in the United States: results of the National Longitudinal Alcohol Epidemiologic Survey. J Stud Alcohol. 1997;58:464-73.

14. Welty LJ, Harrison AJ, Abram KM, Olson ND, Aaby DA, McCoy KP, et al. Health Disparities in Drug - and Alcohol-Use Disorders: A 12-Year Longitudinal Study of Youths After Detention. Am J Public Health. 2016;106:872-80.

15. Salloum IM, Thase ME. Impact of substance abuse on the course and treatment of bipolar disorder. Bipolar Disord. 2000;2:269-80.

16. Dominguez G, Belzung C, Pierard C, David V, Henkous N, Decorte L, et al. Alcohol withdrawal induces long-lasting spatial working memory impairments: relationship with changes in corticosterone response in the prefrontal cortex. Addict Biol. 2017;22:898-910. 


\section{Psihijatrijski poremećaji u iranskih alkoholičara}

Sažetak: - Uvod-postoji uska povezanost između alkoholne ovisnosti i psihijatrijskih poremećaja. Veliki broj ljudi koji konzumiraju alkohol pate od psihijatrijskih poremećaja, stoga identificiranje i liječenje psihijatrijskog poremećaja je od vitalne važnosti kod korisnika alkohola. Cilj ove studija je istražiti prevalenciju psihijatrijskih poremećaja kod iranskih korisnika alkohola u 2017g. Predmeti i metode:- u ovom presječnom istraživanju anketirano je 105 pacijenata koji su bili na iranskom Nacionalnom centru za studije ovisnosti (INCAS). Svi bolesnici ispunjavali su upitnik za konzumaciju alkohola i demografski upitnik, a prevalencija psihijatrijskih poremećaja procijenjena je s SCID-1. Prikupljeni podaci analizirani su s softverom SPSS verzija 22. Rezultati: - oko 45\% sudionika, osim konzumiranja alkohola, nije imalo drugu psihijatrijsku bolest, a 55\% je imalo psihijatrijski poremećaj. 5,34\% imalo je bipolarni poremećaj, a 4,22\% imalo je tešku depresiju, dok je učestalost OCD-a bila 2,5\%. Povijest upućivanja psihijatru bila je 23,8\%, a povijest primanja na psihijatrijsko odjeljenje bila je 16,2\%. Također,kod bolesnika je ispitana upotreba drugih ne-alkoholnih supstanci; najviše se konzumirao opijum sa 26,7\%, a slijedio je kanabis sa 16,2\%. Zaključak:- s obzirom na veliku učestalost psihijatrijskih poremećaja među poremećajima upotrebe alkohola, neophodan je cjelovit intervju i dobivanje povijesti psihijatrijskih poremećaja.

Ključne riječi: psihijatrijski poremećaji, korisnici alkohola, Iran. 
